VOX PATRUM $38(2018)$ t. 70

Rev. Piotr SZCZUR*

\title{
IMAGE AND METAPHOR OF THE SEA IN THE HOMILIES ON THE GOSPEL OF SAINT MATTHEW BY JOHN CHRYSOSTOM
}

The Chrysostom's Homilies on the Gospel of Saint Matthew are the masterpieces of his preaching activity ${ }^{1}$. They were proclaimed in Antioch on the Orontes River probably in the year 390 or $391^{2}$. At that time John Chrysostom was a presbyter ${ }^{3}$ at the site of Bishop Flavian (381-404). It seems, that the

${ }^{*}$ Rev. dr hab. Piotr Szczur, prof. KUL - Chief of Department of Church History in Antiquity and Middle Ages at the Institute of the History of the Church and Patrology at the Faculty of Theology of John Paul II Catholic University of Lublin; e-mail: p_szczur@kul.pl.

${ }^{1}$ Cf. A. Baron, Twórcza przygoda spotkania ze Złotoustym, in: Św. Jan Chryzostom, Homilie na Ewangelię wedlug św. Mateusza, cz. 1: homilie 1-40, ŹMT 18, Kraków 2000, 6.

${ }^{2}$ From the $18^{\text {th }}$ century scientists give the date around the year 390 . Cf. L.S. Le Nain de Tillemont, Mémoires pour servir à l'histoire ecclésiastique des six premiers siècles, t. 11, Paris 1706, 662 - he thinks, that the homilies were proclaimed in the year 391 or a little bit later; B. de Montfaucon, Sancti Patris Nostri Ioannis Chrysostomi Archiepiscopi Constantinopolitani Opera omnia quae exstant, vel quae eius nomine circumferentur, Ad MSS. Codices Gallicanos, Vaticanos, Anglicanos, Germanicosque; necnon ad Savilianam et Frontonianam editiones castigata, innumeris aucta, nova interpretatione ubi opus erat, praefationibus, monitis, notis, variis lectionibus illustrata, nova Sancti Doctoris vita, appendicibus, onomastico et copiosissimis indicibus locupletata, t. 7, Parisiis 1727, $1-2$; t. 8, Parisiis 1728, 2-3 - he thinks, that homilies were proclaimed by Chrysostom between 388 and $390 \mathrm{AD}$; J. Stilting, De S. Joanne Chrysostomo, Episcopo Constantinopolitano et Ecclesiae Doctore, prope Comana in Ponto, commentarius historicus, in: Acta Sanctorum Septembris, t. 4: Quo dies duodecimus, decimus tertius et decimus quartus continentur, Antverpiae 1753, 490-491 he thinks that the Antiochean preached these homilies in 389/390 AD or 390/391 AD; G. Rauschen, Jahrbücher der christlichen Kirche unter dem Kaiser Theodosius dem Grossen. Versuch einer Erneuerung der Annales Ecclesiastici des Baronius für die Jahre 378-395, Freiburg im Breisgau 1897, 527 - he is in a position, that the Homilies on the Gospel of Saint Matthew occured in 391 AD or a litlle bit later; H. Lietzmann, Johannes Chrysostomos, RE IX/2 1817 - he thinks, that they occured after 388 AD, but before 393 AD; M. von Bonsdorff, Zur Predigttätigkeit des Johannes Chrysostomus, biographisch-chronologische Studien über seine Homilienserien zu neutestamentlichen Büchern, Helsingfors 1922, 13-25 - he gives the date of 390 AD; C. Baur, Johannes Chrysostomus und seine Zeit, t. 1: Antiochien, München 1929, 288-289 - he thinks, that the homilies occured around 390 AD; Quasten III 440 - convinces that the homilies occured in 390 AD.

${ }^{3}$ From the end of $380 \mathrm{AD}$ or the beginning of $381 \mathrm{AD}$, Chrysostom was a deacon. He was ordained as a deacon by bishop Meletius. (cf. Palladius, Dialogus de vita Iohannis Chrysostomi 5, 34, éd. A.M. Malingrey - P. Leclercq, SCh 341, Paris 1988, 110; J.N.D. Kelly, Golden Mouth. The Story of John Chrysostom - Ascetic, Preacher, Bishop, New York 1995, 38; C. Tiersch, Johannes 
location of the city in which the Golden Tongued proclaimed his 90 homilies on the Gospel of St. Matthew, essentially influenced on the appearance of many references to marinistic subject in his writings.

The Orontes River ('Opóvचns; now: tur. Asi Neri, arab. Nahr al-Asi), flows through the city of Antioch. The river is heading south-west and 30 kilometers further flows into the Mediterranean Sea near the town of Seleucia Pieria. At the time of Seleucid and Roman Empire was a marine "harbor" of the city", allowing for the communication within whole Mediterranean Sea $\operatorname{area}^{5}$. It is worthy to mention that nearby the city there was the Antiochean Lake (nowadays dried) ${ }^{6}$. It was located north-east from Antioch and was formed by the estuary of the Arkeutos River to Orontes River.

We may be sure, that in such located city a lot of its citizens worked in sailing and fishing 7 . There were also many merchants in Antioch, who worked in oversea trade ${ }^{8}$. Many of the citizens took sea trips. Moreover, as L. Neścior notices, "common presence of that topic in a biblical and classic literature and direct contact with the reality of the sea by a man in Greek-Roman world" 9 favored the development of marinistic subject in ancient Christian literature. These factors caused that the terminology and marinistic subject were not alien to the listeners of the sermons of John Chrysostom. His listeners perfectly understood the marinistic parables used by the Golden Tongued, who was supremely familiar with the sea and sea issues ${ }^{10}$.

Chrysostomus in Konstantinopel (398-404). Weltsicht und Wirken eines Bischofs in der Hauptstadt des Oströmischen Reiches, Studien und Texte zu Antike und Christentum 6, Tübingen 2002, 60). $\mathrm{He}$ was ordained as a priest at the begining of $386 \mathrm{AD}$, but not earlier than February 15th. About the date of his ordination: cf. Baur, Der heilige Johannes Chrysostomus und seine Zeit, t. 1, p. 180; L. Brottier, Introduction, in: Jean Chrysostome, Sermons sur La Genèse, SCh 433, Paris 1998, 11; Kelly, Golden Mouth, p. 38 and 55; Tiersch, Johannes Chrysostomus in Konstantinopel (398-404), p. 60-61. About bishop Flavian: cf. F. Cavallera, Le schisme d'Antioche (IV $-V^{E}$ siècle), Paris 1905, passim; SWP 160; S.J. Voicu, Flaviano di Antiochia, NDPAC II 1979

${ }^{4}$ Cf. Libanius, Oratio 11, 263; G. Downey, A History of Antioch in Syria from Seleucus to the Arab Conquest, Princeton 1961, 16; W. Ceran, Rzemieślnicy i kupcy w Antiochii i ich ranga społeczna (II połowa IV wieku), Wrocław - Warszawa - Kraków 1969, 29-30 and 91; idem, Artisans et commerçants à Antioche et leur rang social (seconde moitié du IV siècle de notre ère), traduction de la langue polonaise par E. Kolańska, édition revue, corrigée et mise à jour par P. Filipczak, Byzantina Lodziensia XVIII, Łódź 2013, 45-46 and 148.

${ }^{5}$ Cf. Libanius, Oratio 11, 264.

${ }^{6} \mathrm{Cf}$. ibidem 11, 260.

${ }^{7}$ Cf. Ceran, Rzemieślnicy i kupcy, p. 86; idem, Artisans et commerçants, p. 140.

${ }^{8}$ Cf. Libanius, Oratio 6, 13; 15, 16; Ceran, Rzemieślnicy i kupcy, p. 91-92; idem, Artisans et commerçants, p. 149-150. Waldemar Ceran (Rzemieślnicy i kupcy, p. 92) claims, that "the great trade of Antioch was by the sea", not by land, and the greatest Antiochean merchants were always connected with the sea trade (cf. ibidem).

${ }^{9}$ L. Nieścior, Motyw pomyślnej żeglugi u Ojców Kościoła, in: Mare nostrum. Morze w historii i kulturze krajów śródziemnomorskich, red. T. Kołosowski, Warszawa $2015=$ SACh 20 (2015) 109.

${ }^{10}$ Cf. Ceran, Rzemieślnicy i kupcy, p. 92. Ceran highlights that "He [i.e. John Chrysostom] is able to give for example the characteristic of the seas" (ibidem, note 72). 
Because of that, the Homilies on the Gospel of Saint Matthew (In Matthaeum homiliae) were chosen as a source base of this paper ${ }^{11}$. Until now, there were no critical edition of these homilies. That is why in this article, the text of homilies prepared by Jean Paul Migne, published in 57th and 58th volume of Patrologia cursus completus. Series Graeca ${ }^{12}$ will be used. The basic elements of Christian symbolics connected with the sea metaphor ${ }^{13}$ in John Chrysostom works will be presented in this article. Our deliberation will be focused only on the texts, which contain the terms: $\pi \dot{\varepsilon} \lambda \alpha \gamma \sigma \varsigma$ and $\theta \dot{\alpha} \lambda \alpha \sigma \sigma \alpha^{14}$.

1. Sea as the element of the Universe. In the John Chrysostom statements, the references to the sea as one of the three component parts of the Universe (with heaven and earth) may be found. The source of that idea is in the biblical cosmology. The Bible says, that God is a creator of heaven, earth and sea (cf. Gen 1:1-10; Acts 4:24; 14:15; Rev 5:13; 10:6; 14:7), and these elements form the essential structure of the Universe ${ }^{15}$. The creation of the world by God was done by His kindness and love to man, because whole world was called to the existence because of man and for man. When the Antiochean says about the sins against God, he wants to convict his listeners how ungrateful they are for their benefactor, who gave them so many benefits. He says:

"What then are His good deeds? He created us when we were not, and made

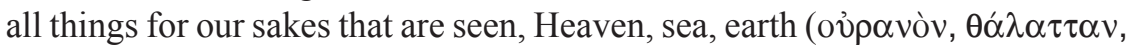

${ }^{11}$ The presence of sea references in John Chrysostom preaching is pointed by R. Zarzeczny (Mare Nostrum - Mare Rubrum, SACh 20:2015, 9).

${ }^{12}$ Paris 1862. The English texts of the homilies will be quoted from the following translation: St. Chrysostom, Homilies on the Gospel of Saint Matthew, ed. P. Schaff, NPNF I/10, New York 1888.

${ }^{13}$ There is indeed a study: E. Śliwka (Symbolika morska w języku Ojców Kościoła, in: Morze w cywilizacji, kulturze i stosunkach międzynarodowych, red. E. Haliżak - W. Lizak - L. Łukaszuk E. Śliwka, Warszawa - Pieniężno 2006, 51-58), but the author never mentions about the metaphor and symbolics of the sea in the writings of the Church Fathers. He just writes about water, cf. ibidem, p. 53.

${ }^{14}$ The term: $\pi \dot{\varepsilon} \lambda \alpha \gamma o \varsigma$ has following meanings: "I. 1. the sea, esp. high sea, open sea; 2. of parts of the sea, freq. with geographical epith. 3. flooded plain. II. metaph., of any vast quantity" (Liddell - Scott, p. 1356); cf. Abramowiczówna III 464. The term: Өó $\lambda \alpha \sigma \sigma \alpha$ $(\theta \alpha \dot{\alpha} \lambda \alpha \tau \tau \alpha)$ has following meanings: "1. sea, freq. of the Mediterranean sea; of a salt lake. 2. sea-water. 3. well of salt water, said to be produced by a stroke of Poseidon's trident, in the Acropolis at Athens. 4. channel" (Liddell - Scott, p. 781-782); "sea" (Lampe, p. 610); cf. Abramowiczówna II 437). These nouns are also used by the authors of the New Testament books to describe the sea (cf. R. Popowski, Wielki słownik grecko-polski Nowego Testamentu, Warszawa 1995, 731, s.v. morze). There are also other Greek terms describing sea, but the usage of them by John Chrysostom is marginal. For example the noun $\lambda i \mu v \eta$, which can mean "sea", but also: "1. a. pool of standing water; hence marshy lake, mere. b. also, artificial pool or basin. 2. in Hom. and other Poets, the sea" (Liddell - Scott, p. 1050; cf. Abramowiczówna III 36), appears in the Homilies on the Gospel of Saint Matthew only once (hom. 33, 3, PG 57, 391) to describe the lake (specifically the Lake of Gennesaret).

${ }^{15}$ Cf. B. Wodecki, Morze w Piśmie Świętym, in: Morze w cywilizacji kulturze i stosunkach międzynarodowych, p. 37. 
$\gamma \hat{\eta} v)$, air, all that in them is, living creatures, plants, seeds; for we must ne-

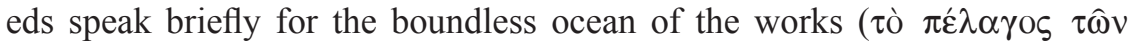
है $\gamma(\omega v) " 16$.

Worth noticing, that in this particular sentence, Chrysostom uses two nouns describing "sea". To describe the real sea he uses the term of $\theta \dot{\alpha} \lambda \alpha \tau \tau \alpha$, and for the description of the multitude of God's benefits given to a man, he uses the noun of $\pi \dot{\varepsilon} \lambda \alpha \gamma \circ \varsigma_{\text {. }}$

Although whole deed of creation is one great benefit done by God to a man, the Antiochean compares it with redemption done by Son of God and claims, that the creation of the Universe (including heaven, earth and sea) cannot be considered as equal to the deed of redemption ${ }^{17}$.

The Golden Tongued underlines the unity of divine persons and their common action and is convinced, that Christ-Word is the Creator of whole Universe. Although the Master from Nazareth never said about that by himself, his miracles confirm that ${ }^{18}$, and it was verbally said by St. John in the Prologue of his Gospel:

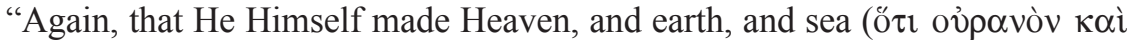

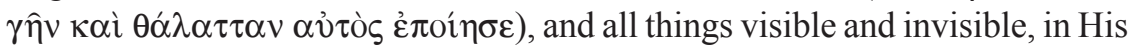
own person He nowhere expressly said: but His disciple, speaking plainly out, and suppressing nothing, affirms this once, twice, yea often: writing that «all things were made by Him;» and, «without Him was not one thing made;» (Jn 1:3) and, «He was in the world, and the world was made by Him» (Jn 1:10)"19.

Alike he did it when he considered God-Father, John Chrysostom claims, that the creation of heaven, earth and sea arose as a result of the kindness and graciousness of Christ to a man ${ }^{20}$, which also underlines the unity of action between particular persons of the Holy Trinity.

${ }^{16}$ Joannes Chrysostomus, In Matthaeum hom. 61, 1, PG 58, 590, NPNF I/10, 376. In English translation the word "earth" is missing. It was added by the author of this paper.

${ }^{17} \mathrm{Cf}$. ibidem 50, 3, PG 58, 508, NPNF I/10, 313: "And if I say, He stretched out the heaven, He

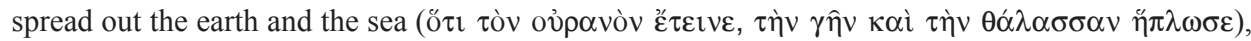
He sent prophets and angels, I say nothing in comparison. For the sum of His benefits is this, that «He spared not His own Son», in order to save His alienated servants".

${ }^{18}$ Cf. ibidem 16, 2, PG 57, 240, NPNF I/10, 104: "Again, that He created the world and all things therein, He demonstrated by the fishes, by the wine, by the loaves, by the calm in the sea ( $\delta$ i $\alpha$

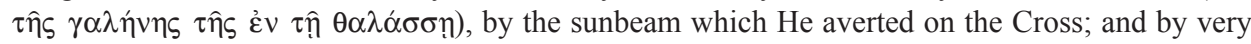
many things besides: but in words He hath nowhere said this plainly".

${ }^{19}$ Ibidem 16, 2, PG 57, 240, NPNF I/10, 104.

${ }^{20} \mathrm{Cf}$. ibidem 23, 8, PG 57, 318, NPNF I/10, 165: "But mark even here His gentleness; in that He doth not at all speak of His benefits, nor say, «Thou hast despised Him that hath done thee so much good»: neither doth $\mathrm{He}$ say, «Me, who brought thee from that which is not into being, who breathed into thee a soul, and set thee over all things on earth, who for thy sake made earth, and heaven, and

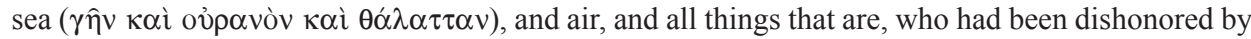
thee, yea accounted of less honor than the devil»»". 
Although the Universe called to the existence by God is indeed magnificent, the Golden Tongued says it is still only a creation ruled by the laws of nature. That is why the preacher teaches his listeners, that every material thing passes. He puts that in simple words, saying: "Yea, for heaven, and

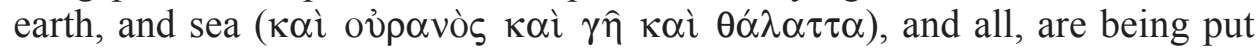
together afresh" 21 .

2. Sea subjected to Christ. Saying about extraordinary deeds done by Jesus, John Chrysostom notices: "But He did not cast out devils only, but also cleansed lepers, and raised the dead, and curbed the sea ( $\theta \dot{\alpha} \lambda \alpha \tau \tau \alpha \nu$ '́ $\chi \alpha \lambda \hat{i}^{-}$ vov), and remitted sins, and preached the kingdom, and brought men unto the Father" 22 . Therefore, using the image of sea, he shows a remarkable power of Jesus Christ. That power manifests itself by ruling over that unusually wild element as sea is, which "respects" Christ and is obedient to $\mathrm{Him}^{23}$. The preacher finds the chance of explanation that issue primarily by commenting part of the Gospel (Mt 8:23-27) ${ }^{24}$, which says about Christ silencing the thunderstorm on the Galilee Lake or Lake Tiberias, also known as "the sea"25. The Golden Tongued by appealing to that story says:

"The tempest therefore being thoroughly excited, and the sea ( $\tau \hat{\eta} \varsigma \theta \alpha \lambda \dot{\alpha} \sigma \sigma \eta \varsigma)$ raging, «They awake Him, saying, Lord, save us: we perish» (Mt 8:26). But He rebuked them before He rebuked the sea ( $\tau \hat{\eta} \varsigma \theta \alpha \lambda \dot{\alpha} \sigma \sigma \eta \varsigma){ }^{\prime 26}$.

When John Chrysostom refers to the same part of the Bible, he notices that every storm in the nature passes and gradually fades. To make any element fully faded we need time. However, the silencing of the storm done by Christ was instant ${ }^{27}$. No wonder that the Antiochean is certain that silencing the storm and wild sea (i.e. the Galilee Lake) by Christ was the manifestation of His divinity, which was proclaimed by tranquil sea. In that context, the Antiochean refers to the healing people possessed by demons done by Christ (cf. Mt 8:8-34), claims that the confessions of unclean spirits expelled from

${ }^{21}$ Ibidem 31, 5, PG 57, 376, NPNF I/10, 209.

${ }^{22}$ Ibidem 32, 2, PG 57, 378, NPNF I/10, 211-212. Cf. ibidem 49, 2, PG 57, 498.

${ }^{23}$ Cf. ibidem 85, 1, PG 58, 757, NPNF I/10, 506: "On that face which the sea, when it saw it,

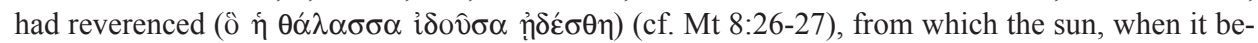
held it on the cross, turned away his rays (cf. Lk 23:45; Mt 27:45)".

${ }^{24}$ Cf. Nieścior, Motyw pomyślnej żeglugi u Ojców Kościoła, p. 118-120.

${ }^{25}$ Cf. F. Gryglewicz, Genezaret, EK V 960; Wodecki, Morze w Piśmie Świętym, p. 43.

${ }^{26}$ Joannes Chrysostomus, In Matthaeum hom. 28, 1, PG 57, 351, NPNF I/10, 190.

${ }^{27} \mathrm{Cf}$. ibidem 27, 1, PG 57, 344-345, NPNF I/10, 185: "For ye know that even after the departing of fevers, the patients yet need much time to return to their former health. But then all took place at

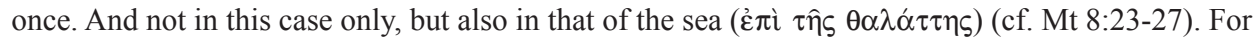
neither there did He quiet the winds only and the storm, but He also stayed at once the swelling of the waves; and this also was a strange thing. For even if the tempest should cease, the waves continue to swell for a long time. But with Christ it was not so, but all at once was ended". 
possessed people are convergent with the testimony given about Christ by the tranquil $\mathrm{sea}^{28}$ :

"they that heard not the sea ( $\tau \hat{\eta} \varsigma \theta \alpha \lambda \dot{\alpha} \tau \tau \eta \varsigma)$ swelling and subsiding, heard from the devils the same cry, as it by its calm was loudly uttering"29.

Because of that the Antiochean calls Christ "the Lord of the sea" ( $\tau \hat{\eta} \zeta$

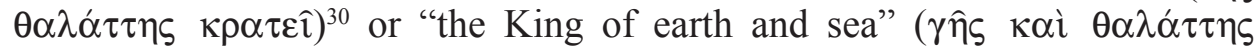

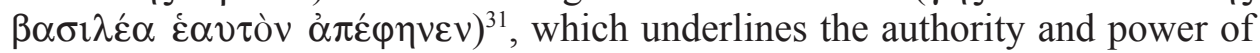
Christ even more.

Commenting this particular part of Gospel by Chrysostom, became for him an opportunity to show to his listeners some christological truth, that Jesus Christ is a true man and true God. Referring to that part of Gospel the Preacher says: "since while the sleep and the outward appearance showed man, the sea $(\dot{\eta} \delta \dot{\varepsilon} \theta \dot{\alpha} \lambda \alpha \tau \tau \alpha)$ and the calm declared Him God" ${ }^{\prime 2}$.

3. Sea as a designation of immensity. In the Homilies on the Gospel of Saint Matthew of Chrysostom the sea is repeatedly shown as immensity, which cannot be embraced and which is beyond other elements of the world by its multitude. John Chrysostom uses this image to show the vastness of God's kindness. Referring to the statement of St. Matthew from the story about the birth of Jesus Christ: "All this took place to fulfill what the Lord had said through the prophet: «Behold, the virgin shall be with child and bear a son, and they shall name him Emmanuel»" (Mt 1, 22-23), he says that the Evangelist proclaimed extraordinary deeds of God done because of Him: "For when he saw the sea and the abyss of the love of God towards man

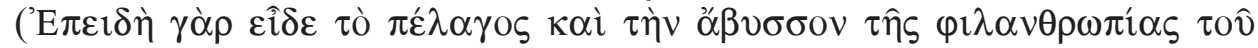
$\Theta \varepsilon \circ \hat{v}$ )" 33 . God shows the immensity of his kindness to all people (inter alia, He fills the sea for them ${ }^{34}$ ), and especially to those, who are able to understand that they sin and they try to improve themselves. When they do that "He gushes out beyond the fountains, He is poured forth beyond the ocean ( $\tilde{\pi} \pi \dot{\varepsilon} \rho$

${ }^{28} \mathrm{Cf}$. ibidem 29, 1, PG 57, 359, NPNF I/10, 196, where is said that Crist manifested his power

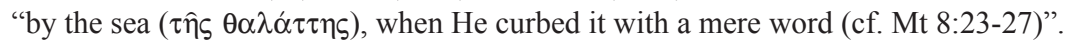

${ }^{29}$ Ibidem 28, 2, PG 57, 352, NPNF I/10, 192.

${ }^{30}$ Ibidem 58, 2, PG 57, 567.

${ }^{31}$ Ibidem 51, 2, PG 57, 512, NPNF I/10, 316: "He had shown Himself King of earth and sea".

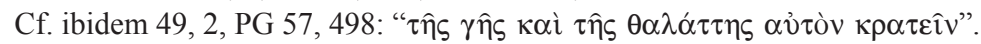

${ }^{32}$ Ibidem 28, 1, PG 57, 352, NPNF I/10, 190.

${ }_{33}$ Ibidem 5, 2, PG 57, 56, NPNF I/10, 32.

${ }^{34}$ Cf. ibidem 13, 5, PG 57, 216-217, NPNF I/10, 86: "But now thou seest Him for thy sake stretching out the heaven, kindling the sun, founding the earth, pouring forth the sea, expanding the air, and appointing for the moon her courses, setting unchangeable laws for the seasons of the years, and all other things too performing their own courses exactly at a sign from Him". 


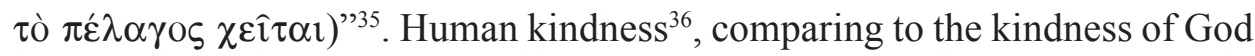
is "as a drop of water to an endless sea ( $\pi \rho o_{\varsigma} \pi \varepsilon \dot{\varepsilon} \lambda \alpha \gamma o \varsigma$ ö $\left.\pi \varepsilon \imath \rho o v\right)$, so much, or rather much more, doth thy love to man come short in comparison of the boundless kindness of God"37.

In Chrysostom exegesis, the sea as an immensity means also the enormity of the torments of hell:

"But we have a sea of fire ( $\pi \dot{\varepsilon} \lambda \alpha \gamma$ ó $\left.\varepsilon^{\circ} \sigma \tau \imath ~ \pi \nu \rho o ̀ \varsigma\right)^{38}$, a sea not like that, either

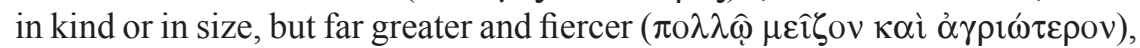

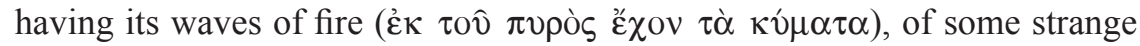

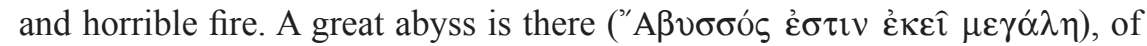
most intolerable flame ( $\varphi \lambda$ oyòs $\chi \alpha \lambda \varepsilon \pi \omega \tau \alpha \dot{\tau} \tau \eta)$ ). Since everywhere fire may be seen roving quickly round, like some savage wild beast. And if here this sensible and material fire leaped like a wild beast out of the furnace, and sprang upon those who were sitting without (cf. Dan 3:22), what will not that other fire do to such as have fallen into it?" ${ }^{\prime 39}$.

4. "Earth and sea" as a designation of commonness. John Chrysostom is convinced that the coming of Christ was foretold everywhere and: "the wit-

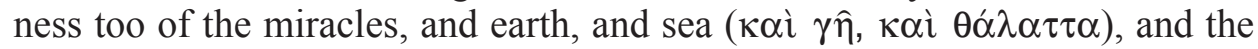
whole creation, uttered in His behalf a distinct voice" ${ }^{40}$. Because of this, the foretold Messiah could be recognized by all creation, described with the term

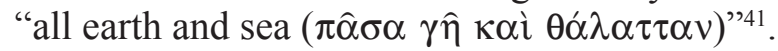

When the Antiochean says about the task given by Christ to his Apostles to proclaim Good News, he underlines that He instructed them to proclaim the Gospel literally everywhere and to everyone. The Preacher puts on the mouth of Christ following words directed to His disciples:

"For not to one, or two, or three cities, but to the whole world ye shall preach,

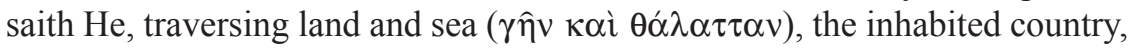
and the desert; to princes alike and tribes, to philosophers and orators, saying all with open face, and with all boldness of speech" ${ }^{\prime 2}$.

${ }^{35}$ Ibidem 22, 6, PG 57, 308, NPNF I/10, 156.

${ }^{36}$ Human kindness was described as to forgive seventy seven times (cf. Mt 18:22; properly saying: seventy times by seven - $\dot{\beta} \delta$ о

${ }^{37}$ Joannes Chrysostomus, In Matthaeum hom. 61, 1, PG 57, 589, NPNF I/10, 376.

${ }^{38}$ The expression "fiery sea ( $\left.\pi \dot{\varepsilon} \lambda \alpha \gamma o ́ \varsigma \pi v \rho o ̀ \varsigma\right)$ " is a clear reference to the apocalyptic designation of hell (cf. Rev 19:20;20:10;20:14; 20:15;21:8). Worth noticing, that the author of the Book of Revelation uses the term: $\lambda \dot{i} \mu \nu \eta$, and John Chrysostom uses the noun $\pi \dot{\varepsilon} \lambda \alpha \gamma o \varsigma$.

${ }^{39}$ Joannes Chrysostomus, In Matthaeum hom. 43, 4, PG 57, 461-462, NPNF I/10, 276.

${ }^{40}$ Ibidem 7, 1, PG 57, 74, NPNF I/10, 44.

${ }^{41}$ Cf. ibidem 10, 3, PG 57, 187, NPNF I/10, 64: “"All flesh shall see the salvation of God» (Lk 3:6; cf. Is 40:5); no longer Jews and proselytes only, but also all earth and sea, and the whole race of men".

${ }^{42}$ Ibidem 34, 2, PG 57, 400, NPNF I/10, 228. John Chrysostom expresses similar thought in 
The terms, which are used by Chrysostom to point the commonness of preaching, are the expressions as follows: "whole world", "lands and seas" and "inhabited and desert earth". Taking into account the context of the considerations presented in this paper, the expression "lands and seas", which describes the commonness of Gospel's proclamation, which is used by the Antiochean quite often. For example, he says that the Apostles did write their writings not to be hidden, but to be read "by sea and by land" ${ }^{43}$. He also says that to their preaching, they are convincing "earth and sea" ${ }^{4}$. The consequence of their evangelical activity was supposed to be the worshiping of Christ all over the world, and so on "earth and sea" and knowing His disciples - unknown till now. ${ }^{45}$.

John Chrysostom uses the expression "earth and sea" when he presents a hypothetical situation, when all laws in the world are abolished. He claims that, if such situation really took place, all previous order would be destroyed, and whole world (and so earth and sea) would plunge in lawlessness and crimes $^{46}$. Likewise, when he says about real wealth, which is a consequence of not material but spiritual goods, the Preacher claims his listeners that the man who would have such a great wealth: "and were possessed of a whole world, and each of them had as many men as are now everywhere on land and

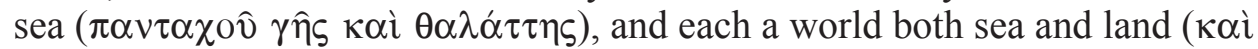

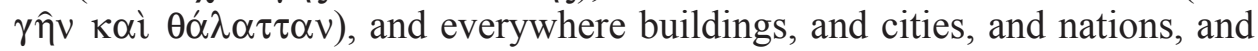

a different place: cf. ibidem 15, 6, PG 57, 231, NPNF I/10, 97: "For «not for your own life apart», saith $\mathrm{He}$, «but for the whole world, shall your account be. For not to two cities, nor to ten or twenty,

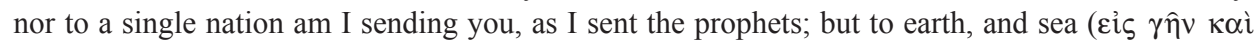
$\theta \alpha \dot{\lambda} \lambda \alpha \tau \tau \alpha \nu)$, and the whole world; and that in evil case»".

${ }^{43}$ Cf. ibidem 1, 4, PG 57, 18, NPNF I/10, 4: "For they did not write these things in one corner and bury them, but everywhere, by sea and by land ( $\pi \alpha \nu \tau \alpha \chi 0 \hat{v} \gamma \hat{\eta} \varsigma \kappa \alpha i ̀ ~ \theta \alpha \lambda \alpha \dot{\tau} \tau \tau \varsigma)$, they unfolded them in the ears of all, and these things were read in the presence of enemies, even as they are now, and none of the things which they said offended any one".

${ }^{44} \mathrm{Cf}$. ibidem: "For things, which they that are without have never been able to imagine, no not in a dream, are by these men with great certainty both published and made convincing, and not in their lives only, but even after death: neither to two men, nor twenty men, nor an hundred, nor

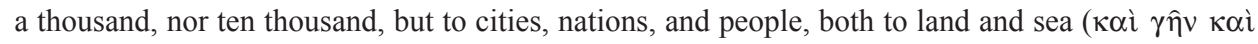
$\theta \alpha \dot{\lambda} \alpha \sigma \sigma \alpha v)$, in the land both of Greeks and barbarians, both inhabited and desert; and all concerning things far beyond our nature".

${ }^{45}$ Ibidem 15, 7, PG 57, 232, NPNF I/10, 98: "For consider how great things he promised to them, who were not known even in their own country: that earth and sea $(\gamma \hat{\eta} \kappa \alpha i$ $\theta \dot{\alpha} \lambda \alpha \tau \tau \alpha)$ should know them, and that they should by their fame reach to the limits of the inhabited world; or rather, not by their fame, but by the working of the good they wrought".

${ }^{46} \mathrm{Cf}$. ibidem 16, 6, PG 57, 246-247, NPNF I/10, 109: "For let us suppose that this law had been altogether done away, and that no one feared the punishment ensuing thereupon, but that license had been given to all the wicked to follow their own disposition in all security, to adulterers, and to murderers, to perjured persons, and to parricides; would not all things have been turned upside down?

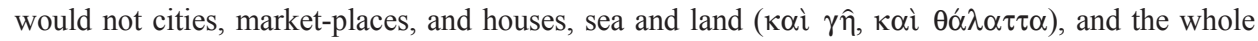
world, have been filled with unnumbered pollutions and murders? Every one sees it". 
from every side instead of water, instead of fountains, gold flowed up for him, I would not say those who are thus rich are worth three farthings, when they are cast out of the kingdom" ${ }^{47}$. Similarly, when he says about morbid greed and cupidity, the Golden Tongued claims, that a man enslaved by the lust of possession would always do whatever he can to get more wealth: "and going

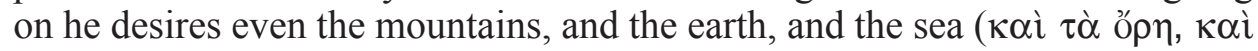

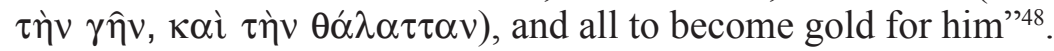

5. Earthly life as a rough sea. When Chrysostom says about human life, he clearly refers it to the image of the sea, claiming that "For our present life

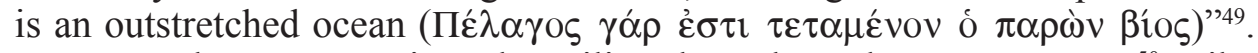
Moreover, he compares it to the sailing throughout the enormous sea ${ }^{50}$. Like the sailors on the sea meet various dangers (winds, sea currents, storms, shallows), it can be found also in human life ${ }^{51}$. For every age: boyish, youthful, manhood and senile, there are particular threats, described in short words by the Antiochean:

"And the first sea ( $\pi \rho \hat{\omega} \tau \sigma o v \pi \dot{\varepsilon} \lambda \alpha \gamma o \varsigma)$ to view is that of our childish days, having much tempestuousness, because of its folly, its facility, because it is not steadfast. Therefore also we set over it guides and teachers, by our diligence adding what is wanting to nature, even as there by the pilot's skill. After this

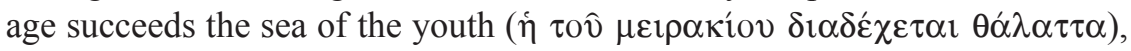
where the winds are violent as in the Ægean, lust increasing upon us. And this age especially is destitute of correction; not only because he is beset more fiercely, but also because his faults are not reproved, for both teacher and

${ }^{47}$ Ibidem 63, 4, PG 57, 608, NPNF I/10, 390.

${ }^{48}$ Ibidem 63, 3, PG 57, 607, NPNF I/10, 390. A little bit further Chrysostom again recalls the image of mountains, earth and sea, explaining that enormous richness, symbolized by the image mentioned above, can only harm a man. Cf. ibidem 63, 4, PG 57, 608, NPNF I/10, 390, 263: "set the

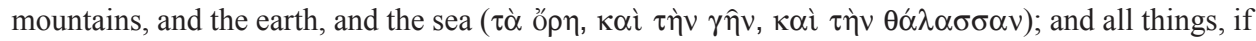
thou wilt, suppose to be gold; for thou shalt see nothing equal to the loss arising to thee from thence".

${ }^{49}$ Ibidem 81, 5, PG 58, 737, NPNF I/10, 490.

${ }^{50}$ This is one of the basic metaphors present in the Fathers of Church writings; cf. Nieścior, Motyw pomyślnej żeglugi u Ojców Kościoła, p. 112 and 114. On the thought of Hieronymus: cf. T. Kołosowski, Porównanie życia chrześcijańskiego do morskiej żeglugi w korespondencji św. Hieronima, SACh 20 (2015) 155-163.

${ }^{51}$ Cf. Joannes Chrysostomus, In Matthaeum hom. 81, 5, PG 58, 737, NPNF I/10, 490: “And as in the sea here, there are different bays exposed to different tempests, and the Ægean is difficult because of the winds, the Tyrrhenian strait because of the confined space, the Charybdis that is by Africa because of the shallows, the Propontis, which is without the Euxine sea, on account of its violence and currents, the parts without Cadiz because of the desolation, and tracklessness, and unexplored places therein, and other portions for other causes; so also is it in our life". This statement cited above is an evidence, that the Preacher knew well particular seas and had a precise knowledge about them. It allowed him to present a brief characteristic of these seas. Worth noticing, that - like above - Chrysostom uses two nouns to describe "sea": $\theta \alpha \dot{\alpha} \lambda \alpha \tau \tau \alpha$ - for the description of real sea and $\pi \varepsilon ́ \lambda \alpha \gamma o \varsigma$ - for the description of human life. 
guide after that withdraw. When therefore the winds blow more fiercely, and the pilot is more feeble, and there is no helper, consider the greatness of the tempest. After this there is again another period of life, that of men, in which the cares of the household press upon us, when there is a wife, and marriage, and begetting of children, and ruling of a house, and thick falling showers of cares. Then especially both covetousness flourishes and envy. When then we pass each part of our life with shipwrecks, how shall we suffice for the present life? how shall we escape future punishment. For when first in the earliest age we learn nothing healthful, and then in youth we do not practise sobriety, and when grown to manhood do not get the better of covetousness, coming to old age as to a hold full of bilgewater, and as having made the barque of the soul weak by all these shocks, the planks being separated, we shall arrive at that harbor, bearing much filth instead of spiritual merchandise, and to the devil we shall furnish laughter, but lamentation to ourselves, and bring upon ourselves the intolerable punishments" ${ }^{\prime 2}$.

John Chrysostom says that the roughness of the sea of life additionally causes an increasing of impetuosity, wrath and desire to insult other people, while the calm of rough waves of life is done by humility and patience. That is why John Chrysostom, using the metaphor of rough sea, contrasts impetuous people to the gentle and says, that the soul of the impetuous is like rough sea $(\pi \varepsilon \lambda \alpha \gamma \varepsilon \varepsilon \kappa \lambda v \delta \omega v i \zeta o \mu \varepsilon v \nu \omega)$, but the soul of the gentle is like a quiet harbor $(\lambda \iota \mu \varepsilon \dot{v} v \tau \alpha \rho \alpha \chi \hat{\eta} \varsigma \dot{\alpha} \pi \eta \lambda \lambda \alpha \gamma \mu \varepsilon \dot{\varepsilon} v)^{53}$. For example, when he refers to the soldiers who committed different kinds of maleficence ${ }^{54}$, he says: "being like wolves, never clear from offenses, unless one might say the sea too was without

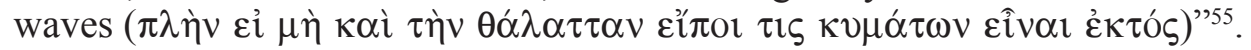

The preacher also calls to mind the monks who lived in the outskirts of Antioch. He says that they ran away from the city noise and chose tranquil life in the mountains. This example is an opportunity for him to contrast their way of life to the life of the citizens of Antioch, who are constantly in a rush and looking for an entertainment in the theaters. And again, referring to the image and metaphor of the sea, the Golden Tongued says that there is a great difference between these two ways of life, "and we shall find the difference between either of these kinds of life as great as between a harbor, and a sea continually

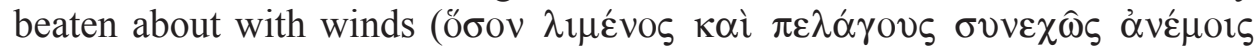

${ }^{52}$ Ibidem 81, 5, PG 58, 737-738, NPNF I/10, 490.

${ }^{53}$ Cf. ibidem 87, 4, PG 58, 773, NPNF I/10, 518-519: "I should like to show what the man is who insulteth, what he that practises self-control, and to bring nakedly before you the soul of the one and the other. For thou shouldest see the one like a sea tost with a tempest, but the other like a harbor free from disturbance".

${ }^{54}$ Cf. P. Szczur, Ojcowie greccy o żotnierzach i stużbie wojskowej, in: Kościót i dar pokoju, red. M. Chojnacki - J. Morawa - A.A. Napiórkowski, Kraków 2016, 325-327.

${ }^{55}$ Joannes Chrysostomus, In Matthaeum hom. 61, 2, PG 57, 590, NPNF I/10, 377. 


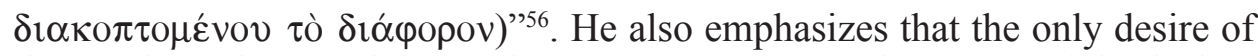
the monks is this: "and that with a pure conscience and many good deeds they may pass through this toilsome life, and sail over the angry sea ( $\tau$ ò $\chi \alpha \lambda \varepsilon \pi$ òv $\pi \dot{\varepsilon} \lambda \alpha \gamma \circ \varsigma)$ with a favorable wind" ${ }^{57}$.

Analyzing the statements of Chrysostom, we it can be clearly noticed, that an earthly life is connected to many worries and spiritual threats ${ }^{58}$. When we take into account such idea of life, we may say that our life is like a sailing on the enormous and rough sea of earthly issues. That idea allows the Preacher to explain to his listeners, that the death is indeed redemption for the people, because it pulls them out from the bulk of worries and threats. Therefore, for the real Christian, the death is a reason for joy, not for sadness ${ }^{59}$. The Preacher understands life as a passage throughout dangerous and rough sea. And he contrasts the dangers and threats of this life to the peace of being in heaven. The heaven is understood as a quiet harbor ${ }^{60}$. Encouraging his listeners to gain humility he presents following argument:

"For thus we shall be enabled both to pass over the sea of this life ( $\tau$ ò $\tau$ ô

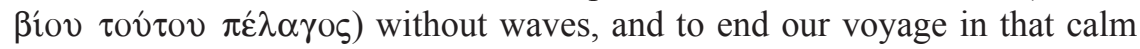

\footnotetext{
${ }^{56}$ Ibidem 68, 3, PG 58, 643, NPNF I/10, 417.

${ }^{57}$ Ibidem, NPNF I/10, 418.

${ }^{58}$ Cf. ibidem 38, 4, PG 57, 433-434, NPNF I/10, 254: "how many troubles and disturbances?
}

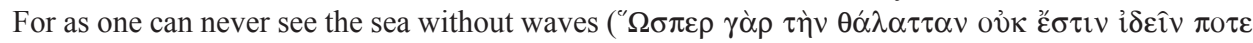

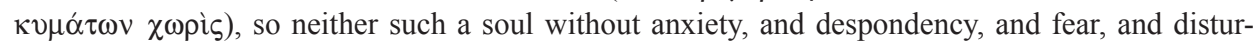
bance; yea, the second overtakes the first, and again others come up, and when these are not yet ceased, others come to a head".

${ }^{59} \mathrm{Cf}$. bidem 31, 5, PG 57, 376, NPNF I/10, 209: "For if thou lovedst the departed, thou shouldest rejoice and be glad that he is delivered from the present waves. For what is there more, I pray thee? What is there fresh and new? Do we not see the same things daily revolving? Day and night, night and day, winter and summer, summer and winter, and nothing more. And these indeed are ever the same; but our evils are fresh, and newer. Wouldest thou then have him every day drawing up more of these things, and abiding here, and sickening, and mourning, and in fear and trembling, and enduring some of the ills of life, dreading others lest he some time endure them? Since assuredly thou canst not say this, that one sailing over this great sea ( $\pi \lambda \dot{\varepsilon}$ ov $\tau \alpha \pi \varepsilon \dot{\varepsilon} \lambda \alpha \gamma \circ \varsigma)$ might possibly be free from despondency and cares, and from all other such things".

${ }^{60} \mathrm{Cf}$. ibidem 19, 7, PG 57, 283, NPNF I/10, 138: "And if while we are in church, and in a short time we have become guilty of so great evils; what shall be when we are gone out from hence? If in the harbor the waves are so high, when we are gone forth into the channel of wickednesses ( $\varepsilon i \varsigma$

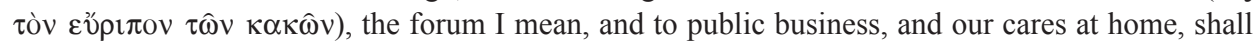
we indeed be able so much as to know ourselves again?" Worth noticing, that in referred statement,

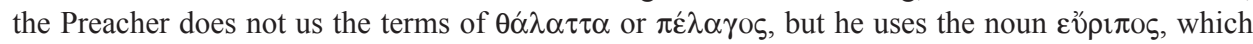
means "I. any strait or narrow sea, where the flux and reflux is violent; esp. the strait which separates Euboea from Boeotia; II. generally, canal, ditch, etc; III. ventilator, fan" (Liddell - Scott, p. 729); cf. Lampe, p. 574: "1. any strait or narrow sea, where the flux and reflux is violent; 2. as adj., troubled, unstable”; Abramowiczówna II 365. 
harbor; by the grace and love towards man of our Lord Jesus Christ, to whom be glory and might for ever and ever. Amen"61.

6. Sea as a dangerous wild element. Chrysostom admires people of the sea, who meet with the unpredictable marine element every day ${ }^{62}$. He praises their courage against rough sea and says that the sea does not terrifies them. And then, he encourages his listeners to have similar courage to endure the adversities of life. He also notices, that the sailors are motivated to gain such courage by the hope of earnings and the wish of getting goods, which are perishing and insignificant in the opinion of the Preacher. Since the hope of gaining insignificant material goods mobilizes sailors to almost heroic deeds in a such strong way, it is all the more, that the hope of gaining imperishable goods should mobilize Christians to courageously face the troubles of life ${ }^{63}$.

The Preacher also admires the solidarity of the sailors. When they see the threat of the destruction of a different ship in a rough sea, they are not like the spectators, who just wait passively for the tragedy, but they immediately develop sails and courageously run for the help those in danger. In this context, the Antiochean notices, that since people of one profession could show the solidarity and kindness to one another in the situation of danger, it is all the more, that all people, who share the same nature, should care about the salvation of their confreres. And when they see the danger for their salvation, they should rebuke them to stop the wave of evil ${ }^{64}$.

${ }^{61}$ Joannes Chrysostomus, In Matthaeum hom. 3, 5, PG 57, 40, NPNF I/10, 20.

${ }^{62}$ Cf. ibidem 26, 7, PG 57, 342, NPNF I/10, 183: "For imagine, I pray thee, some pilot, when he had compassed seas without number ( $\mu \nu \rho i ́ \alpha \pi \varepsilon \lambda \alpha \dot{\alpha} \gamma \eta$ ), and sailed over the whole ocean ( $\tau \eta \dot{v} v$ $\theta \alpha \dot{\lambda} \alpha \sigma \sigma \alpha v)$; after those many storms, and rocks and waves, to sink, having with him a great freight, in the very mouth of the harbor, and hardly with his naked body to escape this grievous shipwreck;

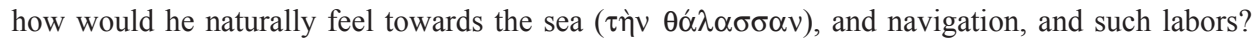
Will such a one then ever choose, unless he be of a very noble soul, to see a beach, or a vessel, or a harbor? I trow not; but he will lie hiding his face, seeing night all through the day, and shrinking from all things; and he will choose rather to live by begging, than to put his hand to the same labors".

${ }^{63}$ Cf. ibidem 23, 5, PG 57, 314, NPNF I/10, 162: "For if to sailors the waves and the seas ( $\tau \dot{\alpha}$ $\pi \varepsilon \lambda \dot{\alpha} \gamma \eta$ ), to soldiers their slaughters and wounds, to husbandmen the winters and the frosts, to boxers the sharp blows, be light and tolerable things, all of them, for the hope of those rewards which are temporary and perishing; much more when heaven is set forth, and the unspeakable blessings, and the eternal rewards, will no one feel any of the present hardships. Or if any account it, even thus, to be toilsome, the suspicion comes of nothing but their own remissness".

${ }^{64}$ Cf. ibidem 15, 10, PG 57, 236-237, NPNF I/10, 101: "Seest thou not the seamen, how, when they see any meeting with shipwreck, they spread their sails, and set out with all haste, to rescue those of the same craft out of the waves? Now, if partakers in an art show so much care one for another, how much more ought they who are partakers of the same nature to do all these things! Because in truth here too is a shipwreck, a more grievous one than that; for either a man under provocation blasphemes, and so throws all away: or he forswears himself under the sway of his wrath, and that way falls into hell: or he strikes a blow and commits murder, and thus again suffers the very same shipwreck. Go thou then, and put a stop to the evil; pull out them that are drowning, 
Describing hard beginnings of proclaiming Gospel, the Golden Tongued refers to the situation on the ship over the rough sea. Doing that and using marine images and terminology, in a very interesting way, he presents to the listeners a dramatic representation of many enormous threats (rough sea, darkness covering the sky, catastrophes of the ships nearby, appearance of sea monsters, and moreover the mutiny of the crew and coming of the pirates) and as a result inevitable catastrophe - the new born Church. All circumstances seem to be in an opposition. But those, who were told to steer the ship and fight against the enemies - as Chrysostom says - succeeded to save the ship in such big danger, despite the fact that they had no experience and they have never seen the sea ${ }^{65}$.

The Preacher mentions also about the sea as a dangerous element in the sense of guiding encouragements to moral perfecting. He expresses, that the good deeds such as: forgiveness, giving alms, canceling unjust debts and fulfilling the commandments are not extraordinary requirements for those who believe in Christ. For example, nobody demands from Christians to cross the sea, what - according to the Golden Tongued - is something extraordinary and requires courage and is associated with great risk. Doing good deeds mentioned above is associated only with good will and the desire of doing good ${ }^{66}$.

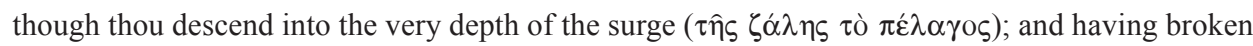
up the theatre of the devil, take each one of them apart, and admonish him to quell the flame, and to lull the waves".

${ }^{65}$ Cf. ibidem 75, 3, PG 58, 689, NPNF I/10, 452-453: "Whence one may most marvel at Christ's power, and their courage, for that they preached in such times, in which most especially the Jewish state was warred against, in which most especially men regarded them as movers of sedition, when Cæsar commanded all of them to be driven away. And the result was the same as if any one (when

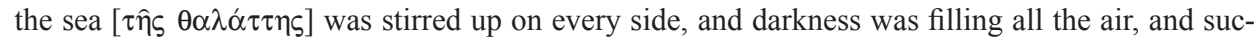
cessive shipwrecks taking place, and when all their fellow-sailors were at strife above, and monsters were rising up from beneath, and with the waves devouring the mariners, and thunderbolts falling, and their being pirates, and those in the vessel plotting one against another), were to command men inexperienced in sailing, and who had not so much as seen the sea $(\theta \alpha \dot{\alpha} \lambda \alpha \tau \tau \alpha \nu)$ to sit at the rudder, and to guide and fight the vessel, and when an immense fleet was coming against them with a great array, making use of a single bark, with her crew in this disturbed state, to sink and subdue the fleet. For indeed by the heathens they were hated as Jews, and by the Jews were stoned, as waging war against their laws; and nowhere could they stand".

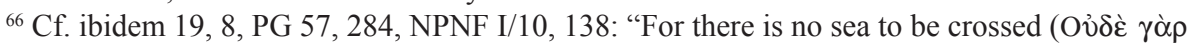
$\pi \varepsilon \dot{\varepsilon} \lambda \alpha \gamma \circ \varsigma \delta 1 \alpha \beta \hat{\eta} v \alpha \imath \delta \varepsilon \hat{\imath})$, nor long journey to be travelled, nor summits of mountains to be passed over, nor money to be spent, no need to torment thy body; but it suffices to be willing only, and all our sins are done away"; 54, 6, PG 57, 539, NPNF I/10, 337: "But what is there at all even hard in these sayings? For neither did He say, «Pass over the mountain, go across the sea ( $\delta$ r $\alpha \beta \eta \theta$ rò $\pi \dot{\varepsilon} \lambda \alpha \gamma o \varsigma)$, dig through so many acres of land, abide without food, wrap thyself in sackcloth»; but, "Impart to the poor, impart of thy bread, cancel the contracts unjustly made»"; 90, 3, PG 58, 790, NPNF I/10, 532: "For what grievous things are we enjoined? to cleave mountains asunder? to fly

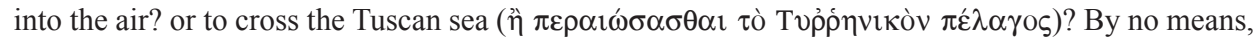
but a way of life so easy, as not so much as to want any instruments, but a soul and purpose only". 
7. Sea and the merchants. In his homilies, the Preacher points out on one negative dimension of overpassing fear associated with dangerous sea journeys. He notices that some people go to the sea run by wicked motivation: greed and the desire of getting rich. Chrysostom criticizes greed and lust of possession and warns from the eagerness of colleting richness, because the richness causes many dangers:

"but for possessions and riches, and the pursuits connected with them, I can show many to have come by their ruin, some in secret, some openly. And with many such instances the highways abound, with many the courts of law, and the market-places. But why speak I of the highways, the courts of law and the market-places? Why, the very sea thou mayest behold filled with their blood

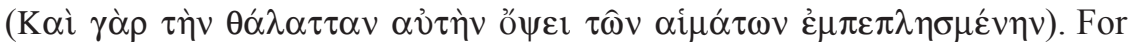
not over the land only, as it seems, hath this tyranny prevailed, but over the

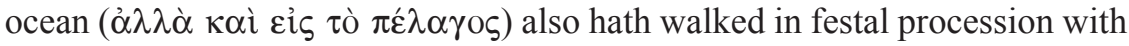
great excess. And one makes a voyage for gold, another, again, is stabbed for the same; and the same tyrannical power hath made one a merchant, the other a murderer" ${ }^{\prime 67}$.

In the text quoted above, Chrysostom says about two kinds of people going on the sea in order to get rich: merchants and pirates. Both groups are run by greed. The merchants risk a lot. They can lose not only a cargo they carry but also their life, for example during the thunderstorm, unfortunate accident or attack of pirates. But even such great threats do not discourage daredevils chasing for profit ${ }^{68}$. On the other side, when the pirates go for the sea journey, they presuppose that they would plunder and kill the merchants.

${ }^{67}$ Ibidem 9, 6, PG 57, 183, NPNF I/10, 60.

${ }^{68}$ Chrysostom many times mentions about the overseas trade merchants. Cf. ibidem 23, 9 , PG 57, 319, NPNF I/10, 166: "Let us, I say, suppose there are two men (and I do not now speak of injuriousness, but as yet of honest wealth); and of these two, let the one get together money,

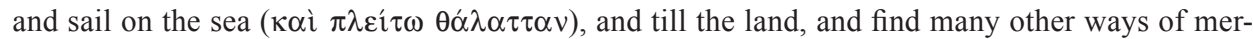
chandise (although I know not quite, whether, so doing, he can make honest gains); nevertheless let it be so"; 59, 5, PG 57, 580, NPNF I/10, 369: "For the merchant too, to increase his wealth, crosses the sea ( $\pi \dot{\varepsilon} \lambda \alpha \gamma o \varsigma$ $\delta 1 \alpha \beta \alpha$ iver); and the artisan, to add to his substance, doeth all things"; 74, 5, PG 58, 686, NPNF I/10, 450: "Forasmuch as a wrestler also, when striving, and winning crowns, would not choose to give up and to be in repose; and a merchant who hath entered on sea ( $\dot{\varepsilon} v \theta \alpha \lambda \alpha \dot{\alpha} \tau \eta\rceil)$ voyages would not desire to be afterwards in idleness". Chrysostom also mentions that merchants go for sea journeys to bring from far lands expensive merchandises to fulfill the sophisticated tastes of Antiocheans and their desire of luxury; cf. ibidem 49, 5, PG 57, 502, NPNF I/10, 308: "Yes: for first a ship is built, then rowers are mustered, and a man for the prow, and a helmsman, and a sail is spread, and an ocean traversed ( $\pi \dot{\varepsilon} \lambda \alpha \gamma o \varsigma \quad \pi \lambda \varepsilon \hat{\imath} \tau \alpha \imath$ ), and, leaving wife and children and country, the merchant commits his very life to the waves, and comes to the land of the barbarians, and undergoes innumerable dangers for these threads, that after it all thou mayest take them, and sew them into thy shoes, and ornament the leather. And what can be done worse than this folly?" 
8. Sea of iniquity. John Chrysostom uses the theme of sea to clearly explain how great havoc is made in moral and spiritual life by drunkenness.

Chrysostom compares its action to the crew of a ship during the storm. Same as the sailors get rid of many material goods and throw a carried cargo out of the ship during the storm, the drunkenness takes all spiritual goods out from the drunkard and throws them into "the sea of iniquity (zis $\tau$ ò $\tau \hat{\eta} \varsigma$ $\pi \alpha \rho \alpha \nu \circ \mu i \alpha \varsigma \pi \dot{\varepsilon} \lambda \alpha \gamma o \varsigma)^{\prime \prime 69}$. All actions taken by the sailors are aimed for saving their lives and the ship, because when the ship is lighter it has more chance to stay on the surface of the sea. However, the action of drunkenness, which takes all the virtues out from the man, is totally reversed: "all abominations of drunkenness" take place of the virtues thrown away, and that eventually results with a tragedy ${ }^{70}$.

The Antiochean also uses the theme of sea to make the believers aware of the immensity of iniquity caused by theatrical shows. He writes some notes about the shows with naked women swimming in water. Probably, it is a testimony that it was able to remodel an Antiochean theater scene to become a pool ${ }^{71}$. Chrysostom notices that watching naked women swimming in a theatrical pool with water called by him "the sea of iniquity": - attracts many viewers. These viewers are not even aware that they destroy their souls and loose themselves in the abysses of lust. As the Golden Tongued says, they call such kind of entertainment: "a sea of pleasure", but in his opinion they should call it "a sea of destruction" 72 . Therefore, it is not surprising that the Preacher encourages the others:

${ }^{69} \mathrm{Cf}$. ibidem 57, 5, PG 58, 566, NPNF I/10, 357: “And like as in a storm when the raging of the waters hath ceased, the loss by reason of the storm remains; so likewise here too. For as there of our freight, so here too is there a casting away of nearly all our good things. Whether it be temperance, or modesty, or understanding, or meekness, or humility, which the drunkenness finds there, it casts

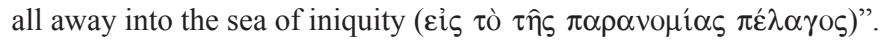

${ }^{70} \mathrm{Cf}$. ibidem: "But in what follows there is no more any likeness. Since there indeed upon the casting out the vessel is lightened, but here it is weighed down the more. For in its former place of wealt hit takes on board sand, and salt water, and all the accumulated filth of drunkenness; enough to sink the vessel at once, with the mariners and the pilot".

${ }^{71}$ More about that: cf. A. Retzleff, John Chrysostom's Sex Aquarium: Aquatic Metaphors for Theater in Homily 7 on Matthew, JECS 11 (2003) 195-207.

${ }^{72}$ Cf. Joannes Chrysostomus, In Matthaeum hom. 7, 6, PG 57, 80, NPNF I/10, 48: "But thou, leaving the fountain of blood, the awful cup, goest thy way unto the fountain of the devil, to see a harlot swim, and to suffer shipwreck of the soul. For that water is a sea of lasciviousness ( $\pi \dot{\varepsilon} \lambda \alpha \gamma o \varsigma$ $\dot{\alpha} \sigma \varepsilon \lambda \gamma \varepsilon i \alpha \varsigma)$, not drowning bodies, but working shipwreck of souls. And whereas she swims with naked body, thou beholding, art sunk into the deep of lasciviousness. For such is the devil's net; it sinks, not them that go down into the water itself, but them that sit above more than such as wallow therein; and it chokes them more grievously than Pharaoh, who was of old sunk in the sea with his horses and his chariots. And if souls could but be seen, I could show you many floating on these waters, like the bodies of the Egyptians at that time. But what is still more grievous is this, that they even call such utter destruction a delight, and they term the sea of perdition a channel for a pleasure

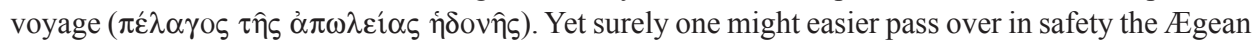
or the Tuscan sea, than this spectacle". 
"If now thou art ashamed, and dost blush at the comparison, mount up to

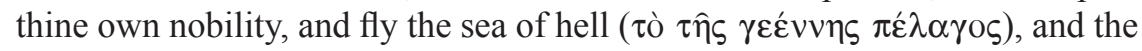

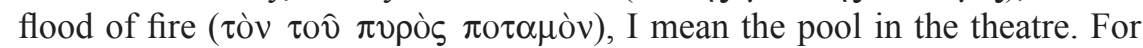

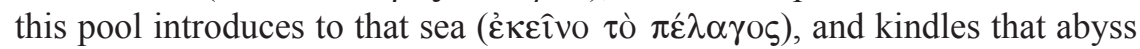
of flame" ${ }^{, 73}$.

The analysis presented above, allowed to see how rich, full of different contents and multilayer the image of sea is in the John Chrysotom's Homilies on the Gospel of Saint Matthew. The Antiochean uses the metaphors associated with the sea to refer them both to God and to a man (especially to the human life). However, the Antiochean uses the term "sea" as a metaphor primarily to describe immensity, vastness and commonness.

\section{(Summary)}

In this article analyzes all statements of John Chrysostom from the Homilies on the Gospel of Saint Matthew containing terms: $\pi \dot{\varepsilon} \lambda \alpha \gamma o \varsigma$ and $\theta \alpha \dot{\lambda} \lambda \alpha \sigma \sigma \alpha$, used by our author as a designation of the sea. This analysis allowed for the extraction of few groups of sea metaphors. Chrysostom points on the sea as one of the elements of the Universe (together with heaven and earth). He describes the sea as a dangerous and uncontrollable wild element, but still subjected to Christ. The image of the sea, which - because of its enormity - is beyond other elements of the Universe, is used by Golden Tongued to describe immensity and commonness. And the reference to sea threats (winds, sea currents, storms, shallows) inclines him to describe human life as a sailing across the rough sea.

\section{OBRAZ I METAFORA MORZA \\ W HOMILIACH NA EWANGELIE WEDEUG ŚW. MATEUSZA JANA CHRYZOSTOMA}

\section{(Streszczenie)}

W artykule przeanalizowano wszystkie wypowiedzi Jana Chryzostoma z Homilii na Ewangelię wedlug św. Mateusza, w których pojawiają się terminy: $\pi \varepsilon ́ \lambda \alpha-$ $\gamma \circ \varsigma$ and $\theta \alpha ́ \lambda \alpha \sigma \sigma \alpha$ używane przez naszego autora na określenie morza. Analiza ta pozwoliła wyodrębnić kilka grup metaforyki morza. Chryzostom wskazuje na morze jako jeden z elementów wszechświata (obok nieba i ziemi). Opisuje je jako niebezpieczny i nieokiełznany żywioł, który jednak poddany jest Chrystusowi.

\footnotetext{
${ }^{73}$ Ibidem, PG 57, 81, NPNF I/10, 49.
} 
Obraz morza, przerastającego swym ogromem inne elementy wszechświata, służy też złotoustemu na określenie bezmiaru i powszechności, a nawiązanie do morskich zagrożeń (wiatry, prądy morskie, burze, mielizny) skłania go do określenia ludzkiego życia do żeglugi przez wzburzone morze.

Key words: John Chrysostom, sea, metaphor of sea, Homilies on the Gospel of Saint Matthew.

Słowa kluczowe: Jan Chryzostom, morze, metafora morza, Homilie na Ewangelię wedtug św. Mateusza.

\section{BIBLIOGRAPHY}

\section{Sources}

Joannes Chrysostomus, In Matthaeum hom. 1-90, PG 57, 13 - 58, 794, english transl.: St. Chrysostom, Homilies on the Gospel of Saint Matthew, ed. P. Schaff, NPNF I/10, New York 1888.

Libanius, Orationes, ed. R. Foerster: Libanii Opera, t. 1-4, [Bibliotheca Scriptorum Graecorum et Romanorum Teubneriana], Lipsiae 1903-1908.

Palladius, Dialogus de vita Iohannis Chrysostomi, éd. A.M. Malingrey - P. Leclercq, SCh 341, Paris 1988.

\section{Literature}

Słownik grecko-polski, red. Z. Abramowiczówna, I-IV, Warszawa 1958-1965.

BARon A., Twórcza przygoda spotkania ze Złotoustym, w: Św. Jan Chryzostom, Homilie na Ewangelię wdtug św. Mateusza, cz. 1: homilie 1-40, ŹMT 18, Kraków 2000, 5-13.

Baur C., Johannes Chrysostomus und seine Zeit, t. 1: Antiochien, München 1929.

BonsdorfF M. von, Zur Predigttätigkeit des Johannes Chrysostomus, biographisch-chronologische Studien über seine Homilienserien zu neutestamentlichen Büchern, Helsingfors 1922.

Brottier L., Introduction, w: Jean Chrysostome, Sermons sur La Genèse, SCh 433, Paris 1998, 11-70.

CaVallera F., Le schisme d'Antioche (IV - Ve siècle), Paris 1905.

CERAN W., Artisans et commerçants à Antioche et leur rang social (seconde moitié du IV siècle de notre ère), traduction de la langue polonaise par E. Kolańska, édition revue, corrigée et mise à jour par P. Filipczak, Byzantina Lodziensia XVIII, Łódź 2013.

CERAn W., Rzemieślnicy $i$ kupcy w Antiochii i ich ranga spoleczna (II połowa IV wieku), Wrocław - Warszawa - Kraków 1969.

Downey G., A History of Antioch in Syria from Seleucus to the Arab Conquest, Princeton 1961.

Gryglewicz F., Genezaret, EK V 960.

Kelly J.N.D., Golden Mouth. The Story of John Chrysostom - Ascetic, Preacher, Bishop, New York 1995.

LAmpe G.W.H., A Patristic Greek Lexikon, Oxford 1976.

Greek-English Lexicon, ed. H.G. Liddell - R. Scott, Oxford 1940.

KoŁosowski T., Porównanie życia chrześcijańskiego do morskiej żeglugi $w$ korespondencji św. Hieronima, SACh 20 (2015) 155-163.

LieTZMAnN H., Johannes Chrysostomos, RE IX/2 1811-1828. 
Montfaucon B. DE, Sancti Patris Nostri Ioannis Chrysostomi Archiepiscopi Constantinopolitani Opera omnia quae exstant, vel quae eius nomine circumferentur, Ad MSS. Codices Gallicanos, Vaticanos, Anglicanos, Germanicosque; necnon ad Savilianam et Frontonianam editiones castigata, innumeris aucta, nova interpretatione ubi opus erat, praefationibus, monitis, notis, variis lectionibus illustrata, nova Sancti Doctoris vita, appendicibus, onomastico et copiosissimis indicibus locupletata, t. 7-8, Parisiis 1727-1728.

Nain de Tillemont L.S. Le, Mémoires pour servir à l'histoire ecclésiastique des six premiers siècles, t. 11, Paris 1706.

NieŚCIOR L., Motyw pomyślnej żeglugi u Ojców Kościoła, w: Mare nostrum. Morze w historii i kulturze krajów śródziemnomorskich, red. T. Kołosowski, Warszawa $2015=$ SACh 20:2015, 109-122.

Quasten J., St. John Chrysostom, w: Patrology, t. 3: The Golden Age of Greek Patristic Literature From the Council of Nicaea to the Council of Chalcedon, Utrecht-Antwerp 1960.

Rauschen G., Jahrbücher der christlichen Kirche unter dem Kaiser Theodosius dem Grossen. Versuch einer Erneuerung der Annales Ecclesiastici des Baronius für die Jahre 378-395, Freiburg im Breisgau 1897.

Retzleff A., John Chrysostom's Sex Aquarium: Aquatic Metaphors for Theater in Homily 7 on Matthew, JECS 11 (2003) 195-207.

Stilting J., De S. Joanne Chrysostomo, Episcopo Constantinopolitano et Ecclesiae Doctore, prope Comana in Ponto, commentarius historicus, w: Acta Sanctorum Septembris, t. 4: Quo dies duodecimus, decimus tertius et decimus quartus continentur, Antverpiae 1753, 401-700.

Słownik Wczesnochrześcijańskiego Piśmiennictwa, red. M. Starowieyski, J.M. Szymusiak, Poznań 1971.

Szczur P., Ojcowie greccy o żotnierzach i stużbie wojskowej, w: Kościót i dar pokoju, red. M. Chojnacki - J. Morawa - A.A. Napiórkowski, Kraków 2016, 307-332.

Śliwka E., Symbolika morska w języku Ojców Kościoła, w: Morze w cywilizacji kulturze i stosunkach międzynarodowych, red. E. Haliżak - W. Lizak - L. Łukaszuk E. Śliwka, Warszawa - Pieniężno 2006, 51-58.

Tiersch C., Johannes Chrysostomus in Konstantinopel (398-404). Weltsicht und Wirken eines Bischofs in der Hauptstadt des Oströmischen Reiches, Studien und Texte zu Antike und Christentum 6, Tübingen 2002.

Voicu S.J., Flaviano di Antiochia, NDPAC II 1979.

Wodecki B., Morze w Piśmie Świętym, w: Morze w cywilizacji kulturze i stosunkach międzynarodowych, red. E. Haliżak - W. Lizak - L. Łukaszuk - E. Śliwka, Warszawa - Pieniężno 2006, 31-50.

Zarzeczny R., Mare Nostrum - Mare Rubrum, w: Mare nostrum. Morze w historii i kulturze krajów śródziemnomorskich, red. T. Kołosowski, Warszawa $2015=$ SACh 20 (2015) 9-24. 